\title{
Joint Child Custody as a New Kindergarten Teachers' Experience
}

\author{
Jana Majerčíková * \\ Received: November 6, 2017; received in revised form: November 22, 2017; \\ accepted: November 23, 2017
}

\begin{abstract}
:
Introduction: The possibility of joint child care after divorce in which parental responsibilities are distributed equally among parents has been implemented in the Czech Republic since 1998. Under certain circumstances, joint custody is considered to be the best solution with regard to further prospects of individual children and also their relationships with their divorcing parents. The solution of joint custody issues happens between parents and/or their family members. Lawyers, psychologists, doctors, and social workers adopt a legitimate attitude to each individual case. Primarily, psychologists provide empirical proofs of the beneficial effect of joint custody concept. In Czech conditions, teachers are the least heard group in this respect.

Methods: A research was carried out in which we utilized the method of thematic writing. Twenty-seven written products, written by the kindergarten teachers were analyzed (the length ranged from 2000 to 2500 words). The content analysis was used with the research aim to reveal their point of view of the joint child custody concept and their experience with children in joint custody.

Results: The teachers' attitude to joint custody was negative, they more leaned towards the opinion that joint custody is not an optimal solution. They perceived the concept of joint custody as beneficial but, on the other hand, as problematic and hardly feasible by divorced people as they often remain in conflict. Based on their experience with children in joint custody, it is fully dependent on the ability of parents to agree on it and to fulfil their children's interests together. However, these are not, according to the teachers, very often taken into consideration in joint custody.

Discussion: In their reflections, kindergarten teachers confirmed the generally accepted controversial conclusions and experience related to primarily practical side of joint custody. They underlined the accepted opinion that it is always necessary to assess joint custody in its relations to a particular case and in respect to its inability to substitute normally functioning and complete families.

Limitaitons: The main research limit concerns the choices of research sample and amount of material based on 27 written products. The first version of the report underwent a participant validation in order to reduce possible distortion during the interpretation of empirical data.

Conclusions: The research results have the potential to introduce further valuable and pedagogical perspective into the discussion about joint custody issues. It can
\end{abstract}

Jana Majerčíková, Tomas Bata University in Zlín, Faculty of Humanities, Zlín, Czech Republic; majercikova@fhs.utb.cz 


\section{Acta Educationis Generalis \\ volume 7, 2017, issue 3}

even serve as a stimulus to optimize the content of teacher education with the aim to encompass various elements of educational reality of current kindergarten.

Key words: joint child custody, kindergarten teacher, research.

\section{Introduction}

In their profession, kindergarten teachers come into contact with children whose family background is often diversified. The key participants who determine its character are undoubtedly parents. It is becoming apparent that what future teachers are prepared for in the context of cooperation with a child's parents in the framework of their teacher education does not fulfil the extent of possibilities reflecting family character of children coming into education (Cimprichová Gežová, 2015, p. 45). Above all, it is direct and particular cooperation with various types of parents. The initial source of starting teachers' discomfort is often the cooperation and effective communication with children's parents, in the worst cases even reality shock. This includes kindergarten teachers as well.

A child from a divorced family is not rare in school nowadays. The specificity of its family background depends even on the form of child care that is practiced after divorce. The subject matter of this study is one of the possible forms of caring for children after divorce, i.e., joint custody, more precisely a child in such family structure on the lowest education level - a kindergarten (hereafter KG).

\section{Theoretical framework}

The pedagogical discourse concerning arguments for the development of optimal relationships with parents leads to the conclusion that the development and success of a child at school is closely bound by the cooperation of school and family. This approach is intensified by a child's age peculiarities in preschool age when the joint parents' and teachers' support of a child, and their mutual participation on the child's development is essential. The situation can become complicated in the case of joint custody (hereafter JC) when a school should cooperate with both parents who are often in an after-divorce conflict. In such case, the cooperation with parents who have a child in joint custody becomes complicated for teachers in kindergartens. Equally demanding is the interaction with a child in joint custody.

KG teachers are supposed to cooperate with parents who are assumed to accept and internalize a certain kind of responsibility, the responsibility towards their own child. Parenthood is a commitment of which fulfilment is given by performing many activities that ensure the survival and complex development of a child (Hoghughi \& Long, 2004). This commitment is, unlike marriage to which a child is often born, irreversible. Marriage and the partnership of parents can be terminated, parenthood cannot.

In situations in which parents choose divorce, their children are affected by the weakening or loss of the feeling of security. The feeling is related to the inability of parents to live together. These children are affected by a "social disorder" of their primary family background without their own contribution (Alan, 1989). The relative unambiguity of a classical interpretative scheme of family influence and the map of family background of a child thus gains modified, sometimes unclear, hardly identifiable contours for both school and teachers. On the background of individual approach to a child, the school and the teachers are expected to reflect on child's new situation. It is 


\section{Acta Educationis Generalis \\ volume 7, 2017, issue 3}

also assumed that the teacher is able to notice and assess signals indicating the child's problems. At the same time, he/she should reduce possible negative influences emerging from the existing family disharmony or try to influence the parents to consider limiting these negative impacts on their child.

It is recognized that divorce is the second most difficult event in life, after the death of a beloved person. For a child, the divorce means, above all, disorientation based on the disintegration of standard patters of relationships between parents and in his/her understanding frequently also disorientation towards him/herself. For example, between the years 1990 - 2000, more than 340,000 children lost everyday contact with one of the parents (usually the father) as a result of divorce in the Czech Republic. This is almost a quarter of the 1.4 million children born to married mothers - ten years also represents the average length of marriage that ended by divorce in the Czech Republic at that time (Pavlík \& Kučera, 2002).

The situation after divorce is difficult for all participants. Generally, the younger the child, the more complicated it is for him/her to handle the circumstances not only in divorce process but also after it when he/she lives in a new environment, most often without the other parent. As for long-term divorce consequences on children, most studies provide great variability among children. In some cases, there were not identified any problems of emotional or psychological nature; on the other hand, some children experienced problems with worse school results, anger management, development of gender identity or psychological adjustment (Lamb, 1995).

However, there is a certain agreement among psychologists that at preschool age, divorce causes higher vulnerability of children, fear of being abandoned by a parent and often even states of anxiety connected to their sense of guilt, disrupted sleep, night terrors, sometimes enuresis (Smith, 2004).

After the divorce, three custody scenarios are possible. The first one is the sole custody of mother, combined with father's visitation rights, the second is the sole custody of father with mother's visitation rights, and the third is the joint custody, when the child alternates between living with his/her mother and father. Because of the attempts to find a way how to decrease the intensity of problems on the side of children, and respecting the rights of both parents, joint custody has been introduced in 1998 in the Czech Republic. It is an alternative to exclusive one-parent custody, when the second parent can visit the child at the weekends.

Joint custody is parental custody in which both parents (who are able to take care of a child and are interested in raising the child and can provide for a healthy upbringing and development of a child) take turns caring for a child in regular time intervals. This arrangement proved to be beneficial for the child. In reality it means that the child "alternates" between his/her mother's and father's places according to agreed plan and rules. Optimal situation includes acceptable distance between homes of both parents and the child should attend just one school. (It is acceptable that the child is educated in two schools when parents live too far away. In this case the time intervals the child spends with one parent are longer, for example half a year, or a year.) Elements of parental responsibility should therefore be divided between both parents. If we ignore the problems caused by material-technical provision of this solution and its financial demands, it is presented as the optimal solution for both parents and the child after divorce. This is, of course, in case the parents are able to communicate and provide necessary conditions. 


\section{Acta Educationis Generalis \\ volume 7, 2017, issue 3}

By taking this step, the Czech Republic made its way among the countries where joint custody has been a viable option for the last twenty years. There are many controversial opinions on joint custody problematics in Czech environment. According to my research, they can be categorized into three big groups. They are the opinions: "for", "against", and "for with conditions", and none of the groups is dominant. Before 1998 the children were automatically given to mothers after divorce in more than $90 \%$ of cases and afterwards very little changed in this respect. Only in 2002, less than $90 \%$ of divorcing mothers $(89.38 \%$ to be precise) were given the sole custody of their children. $7.99 \%$ of divorcing fathers were given the sole custody of their child in 2002 and only $2.14 \%$ of parents were granted joint custody (Pavlát, 2013). Joint custody has been practiced only exceptionally after its implementation in the Czech Republic.

Situation is changing very slowly. In $2007,2.5 \%$ of all divorcing couples with children were granted joint custody (Bartošová \& Slepičková, 2009) and the number has been rising only slowly in the following years. The reasons for this seem to be relatively strongly rooted stereotypes that the mother can provide the best possible care for her child after the divorce. Other reasons include the prejudices regarding parental roles of the father and mother in upbringing of their children. Also the inability of parents to agree on the necessary things in order to have a functional joint custody is counterproductive.

The research of this problematics is rare in the Czech Republic, although it is researched as a part of larger researches. There is no study that would reveal how this custody model works, what accompanies it, what is its genesis and consequences for children. It is possible to use partial research results, mostly published experiences of parents, stances of lawyers, social workers, pediatricians and above all, psychologists. Their experiences are rooted in their clinical practice. Even in the Czech Republic, advocates of joint custody prove its pros by referring to classic information sources (Bauserman, 2002), or experience from other countries (for example USA, Canada, Scandinavian countries etc.). Especially psychologists provide opinions and evidence based on their experience about the benefits of joint custody concepts. Positive stance is, however, presented as the least harmful alternative. We can use a very apt analogy according to which no matter how perfect the artificial limb is, it can never be as good as the real thing. In the same way, no divorce solution can give children an optimal alternative to a functioning and harmonious family (Novák, 2013).

The issues of joint custody are mostly discussed among psychologists, lawyers, and social workers. Teachers are the least heard group. The fact remains that everyday reality of a court's decision impacts even teachers themselves. Kindergarten teachers were approached in order to reveal their opinions and experience during the research.

\section{Methodology}

The research problem I address is the reflection of joint child custody issues under preschool education conditions among their teachers. I have been a part of the kindergarten educational environment as an educator of the teachers. It also includes the education of teachers - professionals who enhance their qualification in the framework of their university studies. Contacts and discussions with these teachers are an interesting source of stimuli for research and provision of background for a relevant expert discussion. It is these contacts that allowed me to carry out this research of which results are further presented. 


\section{Acta Educationis Generalis \\ volume 7, 2017, issue 3}

Considering what research possibilities related to acquiring sources for research data collection were available, I leaned towards the quantitative research direction. It was not only the number of participants that constitute the base source of the research, I was also motivated by the endeavor to research an interesting and not reflected topic that is possible to develop and research with the aim to perspectival optimize even for teacher education.

\subsection{Research aims and research sample}

In order to argument opinions of kindergarten teachers on JC, the aim of the research was:

- to disclose the opinions of KG teachers on JC after the divorce of parents;

- to record and describe the KG teachers experience with children in JC (children in preschool age);

- to disclose possible differences in opinions among teachers based on their experience with children in JC or the length of their pedagogical career.

My ambition was to use the research results in further conceptualization of the joint child custody (preschool age) relying on the opinions of teachers. The aim also was to clarify other aspects of the KG teacher's work and reflect them in the education process of future KG teachers. Relying on the qualitative research direction, the basic research question was selected: How do KG teachers reflect on the joint child care issues?

My research included 17 qualified KG teachers (all of them female), 2 of whom majored in a non-pedagogical discipline Specify.at the university. Participants were simultaneously students of a bachelor degree that was to ensure them the KG teacher university qualification (up to now, university degree in pedagogy major is not a compulsory requirement for $\mathrm{KG}$ teachers). Direct pedagogical experience of participants in $\mathrm{KG}$ ranged from 2 to 15 years and all of them had experience with children in joint custody. We chose these teachers intentionally, whilst we combined theoretical selection (teachers met given requirements - they had experience with children in joint custody) and availability - researcher was to have a good access to participants.

In the second phase of my research, I addressed 10 other teachers, who are students of the master's program (age 21 to 25 years) at the moment. These participants had the necessary qualification for teaching at a kindergarten, finished their bachelor study program and did not have direct experience with children in joint custody; their kindergarten teacher experience was limited to pedagogical practice during their bachelor studies. Their experience with JC was bound to random personal contacts with their environment, not from the kindergarten environment where they taught.

\subsection{Method of data collection and data processing}

I used content analysis of products to fulfil my research aims - written texts (Gavora, 2007). In this case it was thematic writing. Usage of written texts appeared to be an interesting choice when planning the data collection, as it had a potential to demonstrate personal opinion and mediate participants' own beliefs (Wiegerová \& Gavora, 2014). We chose unrestricted authorial writing, teachers created texts on a given topic and the extent and time, dedicated to writing, was not limited in order to provide space for personal statement. Researcher selected a topic - "A Child in Joint Custody in Kindergarten - my opinions and experiences". Researcher did not categorize the writing or interfered in writing process. 


\section{Acta Educationis Generalis \\ volume 7, 2017, issue 3}

When processing the data, we used qualitative content analysis of 27 verbal statements. When choosing the method of content analysis (as there are several of them), it is necessary to consider the character of data, which is in my case the texts. In participants' thematic writing there were passages which were thematically connected to several aspects of the given topic (opinions, experience, perspectives). They differed in length and declared opinions. Texts, which ranged from 2,000 to 2,500 words, were divided into segments - units of meaning related to the participant and research aims. Then, by open coding, meanings in segments were identified and given a code. Individual segments were read several times, codes were adjusted and reviewed with the intention to capture the range of data as best as possible. Then the codes were divided into categories with similar meaning, then described and explained. For the purposes of this study we conceptualized the codes into three dimensions.

\subsection{Research limitations}

In my research it is necessary to reflect on the limitations one must count on in this context. Those limitations include especially the research sample and the amount of data, which is 27 written products. In my research I admit that intentionality of the sample selection can indicate decreased credibility (Gavora, 2015). In such case, the decreased credibility could be caused by the fact that the selected teachers-professionals (enhancing their qualification) were a part of the academic environment, they gained and improved their theoretical knowledge, they enhanced their pedagogical competences in order to work in KG. Teachers to be who have already finished half of the bachelor degree studies and they have not dealt with the problematics of joint custody explicitly. It is admissible that their opinions and preferences regarding the topic, their professional self-confidence and assessment of experienced situations might be influenced by their studies. Regarding the amount of data, 27 is rather a low number. However, given the extent of the written material I captured certain theoretical saturation, as I identified similar patterns in the data from the teachers. Those data served as the basis for the reflection of joint custody problematic.

It is clear that the limitations of each, especially qualitatively oriented research, is the data analysis itself. In order to improve validity of my research and to reduce possible distortion of the results, the first draft of research report was presented to one of the participants, so she could validate it. In order to rectify possible disproportions that may have emerged by data interpretation, I discussed the results with the participant. Consequently, I reflected on her comments and specified connotations of certain statements and I adjusted the research results.

\section{Results}

27 texts whose length ranged from 2,000 to 2,500 words were analyzed. As was stated above, these data were divided into segments and then processed by open coding. Codes were categorized with the ambition to gain more abstract conceptualization of collected data. Descriptive approach was used. Table 1 contains the list of extracted categories that outline perspectives of researched teachers. 


\section{Acta Educationis Generalis \\ volume 7, 2017, issue 3}

Table 1

An overview of dimensions and categories

$\begin{array}{ll}\frac{\text { Dimension }}{\text { Teachers personality and professionalism }} & \begin{array}{l}\text { Category } \\ \text { Teacher as a child and parent } \\ \text { Teacher as an expert }\end{array} \\ & \begin{array}{l}\text { Emotions in supposed professionality } \\ \text { Reality of joint custody according to the }\end{array} \\ & \begin{array}{l}\text { Reaction and impact on a child } \\ \text { Questioning parental competences } \\ \text { teachers }\end{array} \\ & \begin{array}{l}\text { To speak with the child } \\ \text { Omnipotent communication }\end{array} \\ \text { Opinion platform as a point of departure } & \text { Controversial topic } \\ & \text { It cannot work because... } \\ & \text { It can work if... }\end{array}$

4.1 Teachers personality and professionalism in joint custody

In the data collected from teachers I conceptualized three dimensions related to the problematics. The first one touches teachers themselves. In Table 1 three categories relate to it. Problematics of joint custody is reflected by teachers through the prism of their own experience from family. They mixed their own good memories from childhood and the presence of both parents, in contrast to what quality they see in childhood, or how they assess it in case of JC children in kindergarten. The role of a parent, especially the emotional ties to their own children (who are part of this role) served as the filter, through which the teachers filtered their general opinions on JC.

"I grew up in a harmonious family, so, I cannot imagine that I would go from my mother to the father... Simply, I cannot imagine that. I could never do that to my children."

In the work of kindergarten teachers, I identified the manifestations of the maternal approach, and as one of them rightly states, this approach complicates their work to a certain extent.

"The most difficult thing is to stay objective and to think over the optimal approach from the long-term perspective and in the larger framework of a child's prosperity. This is difficult because of protective and maternal instincts of the teacher. A bit paradoxically those things that are her very own in an increased degree and what is also one of the primary motives leading to her choice of employment. Therefore, it is difficult for her to face it - her heart just feels like ,squeezed" and wants to hug and soothe the child; at night, she just stares at the ceiling and thinks how to carry out her "mission in life further."

An experienced emotional strain contributes to the stated difficulty. The strain comes from shared feelings and reactions of the children that have to experience changing of two family environments. It is interconnected with one's own parenthood and an unacceptable image of possible suffering of the children if they would be in joint custody.

"Try to answer the child's question: should I do it as my mother says, or as my father says, or if his mother really loves him. It is very difficult sometimes; their shyness and insecurity are utter despair."

The students - participants that had minimum practical kindergarten experience also stated sorrow over a loss, in some cases even suffering, which children get after divorce. 


\section{Acta Educationis Generalis \\ volume 7, 2017, issue 3}

Including even the case or because of their own experience with living only with one parent after divorce. The idea of changing environment was unacceptable for them. It was accompanied even by fear and concerns how difficult it will be to work with a child in JC in a kindergarten.

The role of a child, a parent and requirements resulting from the professional role of a teacher were brought into the perspective of a child in JC through the eyes of the teachers. The work with children in JC requires certain expert skills related to continuous education and consultations with other experts, e.g., psychologists. Listening to "voices of children" is considered to be the means for better understanding of the child learning at the preschool facilities (Navrátilová, 2017). The perceived difficulty in contact with children in JC and their parents is indicated by imbalances in the behavior of these children and parents and collides with fragile professionalism of kindergarten teachers.

"We formulated a report on how a child prospers in parental care. Otherwise, work with children and parents is difficult. We have to prepare for that somewhere, study literature, and consult problems with a psychologist. I am not sure, I am not always able to respond. It is also very difficult with the parents."

\subsection{Reality of joint custody according to the teachers}

The second dimension that I constructed based on written responses of participants integrates those aspects of joint child custody that origin as a reflection of particular situations with which the teachers are confronted. It includes four more categories in Table 1.

All participants absolutely agree that the importance attributed to communication is great. They consider it as key for optimal functioning of JC in everyday reality. Communication between parents was declared as the most important one.

"Everything is built on communication, how everything is communicated."

They confirm the fact that JC can be implemented only between partners who are able to agree and consequently effectively cooperate (Novák, 2013). The teachers stated that communication has the possibility to become a "magical wand" that can solve many issues. They relate its importance even to the cooperation with school, thus to communication with teachers.

"The basis is effective communication between parents, parents with the child, and us. If we do not inform each other, we cannot help each other."

Attitudes to JC are reflected by the experience of participants with children and parents. What resonates in the minds of participants are observed changes in a child's behavior during divorce. Every day they notice unconcealed wish for physical contact with the teacher, separation from the collective of other children, sometimes attempts at catching attention to themselves, aggressive behavior or intentional breaking of rules and sentimentality.

"I observe tendencies including cuddling. Sometimes, on the other hand, pulling away or aggression and tendencies to show off. Undoubtedly, increased is also the degree of affective responses. I think these responses are related to the situation at home. Every child has its own manifestations of behavior, they are, however, different as most of the others."

What is mostly emphasized by the participants - independently of practice and experience - is confusion. It is some kind of disorientation of the children which is related to the uncertainty in their home environment. They put it in the context even with 


\section{Acta Educationis Generalis \\ volume 7, 2017, issue 3}

insufficient communication and the explanation of the situation in the family by the parents.

"No one talks with the child about the situation between the parents. It is not enough to say that the mother and father do not understand each other. The worst is when parents do not deal with the situation at home, do not analyze what is really bad, and use the child as a means of revenge or manipulation. That is inconceivable."

According to the teachers, parents in JC fail in the ability to reach into the experience, the specific world of their children. The degree of their empathy and cognition of mechanisms that influence the quality of the internal life of the child is in the interpretation of the teachers cover by a personal interest. As they perceive it, it seems as if the needs of the child are sidelined and the rights of the father or mother or put forward. Although their personal interest can be fulfilled at the expense of the child unknowingly, based on the signals coming from the parents, the participants assess this as their parental failure.

"If the parents at least suspected what is going in the mind of their child, they would not act like that."

"I think the child does not know "whose he/she is", thus it is a "puppet" the parents toy with as they see fit. And before he/she grows up, matures and is capable to judge what the real situation is, it is too late. Mothers in most cases cannot get over this unpleasant situation and in this imbalanced relationship change the surname of their children."

\subsection{An opinion platform as a point of departure}

The last dimension that completed the sketch of the research issues in the perspective of the teachers were opinions related to the practicability of JC. These are the last three categories included in Table 1. Therefore, these are opinions of JC that are based not only own experience but also on theoretical knowledge the teachers were supposed to acquire during their work with children in JC or studies. The opinions of participantsstudents with minimum practical experience unwind from their overall understanding of what happens in kindergarten. Personal contacts with young parents practicing JC proved to be very strong (friends, acquaintances).

In their responses, the teachers state that the issues of JC are a controversial topic based on contradictory opinions. It is obvious even from the statements of social workers, lawyers, psychologists that are available on the internet. As is shown further, the diversity of opinions is obvious even in the case of researched kindergarten teachers.

"Joint custody is very attractive in the theoretical sense, but very treacherous in the practical one."

The teachers evaluated the JC concept as very problematic, almost impracticable. Their reservations were based on the typical objection related to the issue that a child cannot alternate two homes, cannot manage to go from one home to another.

"The child loses certain and is not satisfied. Altering home is unnatural, like come and go."

"Where does the child belong? Where is his/her home?! I can see only a negative impact on the child. He/she experiences alternations of not only different sets of rules but also of homes, has to respect different rules. At each parents' home, there is a different system. The children do not have certainty, they almost do not know where their home is. Furthermore, I think that the child experiences even fear of disappointing one of his/her parents." 


\section{Acta Educationis Generalis \\ volume 7, 2017, issue 3}

However, there were more rational voices among the participants - these voices tried to analyze the advantages and disadvantages of JC. They evaluated JC as implementable, but parents have to be able to agree and subsequently honor their mutual agreement. The attitude is based on the key idea of JC. The child has two parents and if they are able and willing to participate on his/her upbringing even after divorce, both of them should be allowed to. The teachers emphasized the interest of the child that does not lose love, help, and the influence of the mother and father. As an inevitable condition they declared the ability to cooperate in their partnership which did not end with divorce.

"I am a supporter of JC. Both parents are the most important people for in the life of a child. Children should have the possibility to be with both parents. Absolutely inevitable, however, is their mutual agreement."

The teachers-participants declared as an optimal solution regime in which the parents alternate. However, they quickly add that financial and personality possibilities of parents for this strategy is almost unattainable.

\section{Discussion and conclusions}

In their reflections, kindergarten teachers confirmed generally accepted conclusions and experiences (which, however, are not a subject of research argumentation in the Czech Republic) regarding JC. Overall, it is possible to consider their attitudes as negative ones, they tended to hold the opinion that joint custody is not an optimal solution for the child of preschool age after the divorce of his/her parents. In this respect, there was an agreement regardless of the length of their preschool education among the teachers. The liberal, smaller part of them supports JC. Thus, they support the basic psychological concept that the relationship between the child and the father, and the child and the mother, is not similar in its nature, but both relationships complement one another. They are different, but congruent (Pavlát, 2013).

The Czech psychologists are in agreement as regards the age range, in which joint custody is a good solution for the child. They agree that for children older than three it is a viable possibility (Novák, 2013; Klimeš, 2009) and the child is capable of dealing with the circumstances connected to alternating between his/her primary environment. At this age the psychologists do not expect fatal negative reactions from the child. The reason for disagreement with an earlier application of JC are not only a close bond and its irreplaceability between the mother and the child, but also a child's inability to understand the abstract concept of time and the change of the environment at mother's and father's place.

The research shows that the teachers filtered their reflections through the interest and wellbeing of the child and paid practically no attention to parents' stimuli, motivations or needs for this kind of post-divorce arrangement. Parents' motivation, behaviour or reactions was disregarded by the teachers, interest and needs of a child were of prime importance for them. In this we can see their relatively close focus on a unique child agent when performing their job. In Czech environment the value of a child and motherhood is considered an emotional investment and it is expected that it will have rather emotional than material benefit (Mareš, 2005).

Empirical data confirmed the main problem of JC according to $\mathrm{KG}$ teachers, with regard to the role they play. It is a certain diversity when satisfying the needs of a child after divorce. According to teachers, there are two basic, but opposing requirements in it. Above all, the child needs both parents and stability in a family, which is for children the 


\section{Acta Educationis Generalis \\ volume 7, 2017, issue 3}

source of security. Child in JC has both parents, but on the other hand s/he is deprived of the second important need, as constant changing, disorientation and inability of parents to stabilize the situation causes insecurity. Is it possible to harmonize the needs of both parties? This seems to be a trivial question. The answer is complicated when it comes to the reality of JC. It is quite a dilemma that $\mathrm{JC}$ is not for everybody and it is necessary to assess it individually. It is also necessary to consider the fact that it is an alternative solution and it is not capable of supplementing a normal functioning family. Also because of that, JC remains a disputable topic, which proves to be a rich research topic. Undoubtedly, it is one of the possibilities how to care for a child after divorce.

According to the teachers, parents who divorced (and therefore ended a conflict or a problem) are automatically unable to agree on anything, even if it involves their child. This is in agreement with statement (Bauserman, 2002) that is also suggested by the conclusion - that the $\mathrm{JC}$ is not a good solution if there is a raging conflict between parents. In our case we can also say that even if we are aware of modern findings on the importance of love and care fathers provide, it is difficult, or even impossible for the child to profit from the care of both parents when those can cooperate very little or there is a conflict between them, regardless of the post-divorce arrangement in which the child lives. It is vital for a child's wellbeing if both parents are able to define themselves not as a divorced couple, but as parents who cooperate in order to care for their child (Pavlát, 2013).

According to the teachers, successful implementation of JC is dependent on parents, however, as they think, parents are not mature enough for such a solution. In this context it is necessary to mention that the situation is even more difficult because according to current laws about JC in the Czech Republic, agreement of both parents with JC is not a requirement (Trávníček, 2015). We can only guess what is happening in families in which one parent does not agree with $\mathrm{JC}$, yet it is approved by the court. Even when the parents try to make JC work, according to teachers, under such circumstances it just cannot work.

The picture of JC drawn by the teachers-participants does not have the potential to be generalized. It is rather a record documenting interpreted particular states, circumstances, situations in families of individual children in JC. The attitudes of kindergarten teachers have the potential to introduce a new perspective into the discussion related to JC. They are also a stimulus to the development of teacher preparation so that teachers are - in educational reality - able to competently respond to all specific challenges accompanying their profession.

\section{Acknowledgement}

This study was written thanks to the project "Preventing reality shock of future kindergarten and elementary school teachers at the beginning of their teaching career at the Faculty of Humanities, Tomas Bata University in Zlín, financed by the Czech Fund of Educational Policy of the Ministry of Education, Youth and Sports. 


\section{Acta Educationis Generalis \\ volume 7, 2017, issue 3}

\section{References}

Alan, J. (1989). Etapy života očima sociologie. Praha: Panorama.

Bartošová, M., \& Slepičková, L. (2009). Složení rodiny a perspektiva dětských aktérů. Sociální studia, 4, 73-90.

Bauserman, R. (2002). Child adjustment in joint-custody versus sole-custody arrangements. Journal of Family Psychology, 16(1), 91-102.

Gavora, P. (2007). Sprievodca metodológiou kvalitatívneho výskumu. Bratislava: Vydavatel'stvo UK.

Gavora, P. (2015). Obsahová analýza v pedagogickom výskume: Pohl'ad na jej súčasné podoby. Pedagogická orientace, 25(3), 345-371.

Cimprichová Gežová, K. (2015). Father's and Mother's Roles and Their Particularities in Raising Children. Acta Technologica Dubnicae, 5(1), 45-50. doi: 10.1515/atd2015-0032

Hoghughi, M., \& Long, N. (2004). Handbook of parenting: theory and research for practice. London: Sage.

Klimeš, J. (2009). Stř́davá výchova a styk s dtětem po rozchodu. Retrieved from http://klimes.mysteria.cz/clanky/psychologie/stridava_vychova.pdf

Lamb, M. E. (1995). Paternal influences on child development. In van Dogen et al. Changing Fatherhood: An Interdisciplinary Perspective (pp. 145-158). Amsterdam: Thesis Publishers.

Mareš, P. (2005). Hodnota ditěte na přelomu tisíciletí - Česká republika, 2005. Retrieved from http://www.infostat.sk/vdc/pdf/tajov/Mares.pdf

Navrátilová, H. (2017). Children's Initiations in Communication with Preschool Teachers. Acta Educationis Generalis, 7(2), 42-55. doi: 10.1515/atd-2017-0012

Novák, T. (2013). Stř́lavá péče o dítě. Praha: Portál.

Pavlát, J. (2013). Problémy studií argumentujících pro střídavou péči”. Bulletin advokacie.cz. Retrieved from http://www.bulletin-advokacie.cz/problemy-studiiargumentujicich-pro-stridavou-peci?browser=mobi

Pavlík, Z., \& Kučera, M. (2002). Populační vývoj České republiky 1990-2002. Praha: Demoart.

Smith, H. (2004). Děti a rozvod. Praha: Portál.

Trávníček, M. (2015). Stř́idavé péče. Praha: C. H. Beck.

Wiegerová, A., \& Gavora, P. (2014). Proč se chci stát učitelkou v mateřské škole? Pohled kvalitativního výzkumu. Pedagogická orientace, 24(4), 510-534. 